\title{
Why we need to know what and where cows are urinating - a urine sensor to improve nitrogen models
}

\author{
K. BETTERIDGE, D. A. COSTALL, F.Y. LI, D. LUO and S. GANESH \\ AgResearch Grasslands, Private Bag 11008, Palmerston North \\ Keith.betteridge@agresearch.co.nz
}

\begin{abstract}
Urine of grazing livestock is the greatest contributor to leached nitrogen $(\mathrm{N})$ in our environment. While many $\mathrm{N}$ cycling models have used average urine excretions as input data, concentration and volume of individual urination events can vary greatly. Stock camps receive large amounts of urine and pose a high risk of $\mathrm{N}$ leaching, especially when animals are set stocked over several days. Anew urine sensor is described, along with the variation in urine characteristics of break-grazed cows. $\mathrm{N}$ leaching was modelled based on sensor data collection, and paddock-scale estimates were compared to those based on average urine data. There was a $10 \%$ difference in estimated $\mathrm{N}$ leached by two pumice soils, but both leached $10 \%$ less $\mathrm{N}$ when varying urine values were used compared to average urine values. The new data showed a frequency distribution pattern of urinary $\mathrm{N}$ concentration in urination events that differed to that estimated using earlier data. Thus, frequency distribution patterns have a large effect on modelled $\mathrm{N}$ leaching loss and need to be based on extensive data collection to increase the confidence in improving estimates of $\mathrm{N}$ leaching. Campsites, which occupy $5-15 \%$ of a hill country paddock, account for about half of all excreted urine; their locations can be predicted for the targeting of N-loss mitigation strategies using a simple topographic map of the farm.
\end{abstract}

Keywords: nitrogen leaching, urine volume, environment, urinary nitrogen concentration

\section{Introduction}

Betteridge et al. (1986) described wide ranges in urinary nitrogen concentration ([N]) and urine volume amongst individual urination events by grazing steers, with urination frequency being 13-73 times/day, urinary [N] being $0.8-14.1 \mathrm{~g} \mathrm{~N} / \mathrm{L}$ and urine volume being $5.8-54.7$ L/day. More recently, a simple urine sensor (Betteridge et al. 2010b) logged the time of each urination event by grazing cows. When coupled with global positioning system (GPS) positions of the cow, urine distribution patterns within a paddock could be mapped within a Geographical Information System (GIS). In hill country paddocks, beef cows were shown to excrete about 50\% of all urination events within $5-15 \%$ of the paddock area (Betteridge et al. 2010a,b), with these sites being typically found in low elevation, low-slope areas of the hill paddock.

Betteridge et al. (2010a) obtained similar results in a small steep paddock at the AgResearch Ballantrae Research Station, using heifers fitted with a GPS, motion sensor (standing, lying, grazing, walking) and a simple urine sensor. A Generalised Additive Model best predicted where stock camps (critical source areas of N; CSAs) would be found in a paddock, based on the independent variables slope, elevation, aspect, Northings and Eastings, in $25 \mathrm{~m}^{2}$ grid cells overlying the paddock map (Betteridge et al. 2012). The correlation between lying time and urine deposition was $r=0.64$. Because few GPS data from grazing animals have corresponding urine deposition data to confirm CSA locations, a CSA site prediction model was developed, based only on cow GPS data (Betteridge et al. 2013), where average velocity was used as the proxy for lying, with the threshold for lying being $\leq 0.011 \mathrm{~m} / \mathrm{sec}$.

Targeting the application of a nitrification inhibitor such as DCD at predicted CSAs allows significant cost savings to be achieved (Betteridge et al. 2011). However, $50 \%$ of the urination events may not deliver $50 \%$ of excreted urinary $\mathrm{N}$, since most concentrated urine is often excreted during the night, until sunrise, when animals rise and start to graze (Betteridge et al. 1986). To determine where urine patches with the greatest $\mathrm{N}$ load have been excreted, a urine sensor that quantifies urinary $[\mathrm{N}]$ and urine volume was required. This paper describes a new urine sensor and the potential value of data obtained for estimating $\mathrm{N}$ leaching compared to predictions using average urine values.

\section{Methods \\ Identifying camp sites}

The contour map of a Ballantrae paddock (Betteridge et al. 2010a) was overlaid with a $5 \mathrm{~m} \times 5 \mathrm{~m}$ grid and GPS animal tracks were superimposed upon it. Using the GIS, accumulated time spent by all monitored animals in each grid cell was used to identify lying areas. The average travel speed for every passage of a cow through the grid cells was determined (Betteridge et al. 2013); when cow speed was $\leq 0.011 \mathrm{~m} / \mathrm{sec}$, the animal was deemed to be lying. This "Lying Threshold 


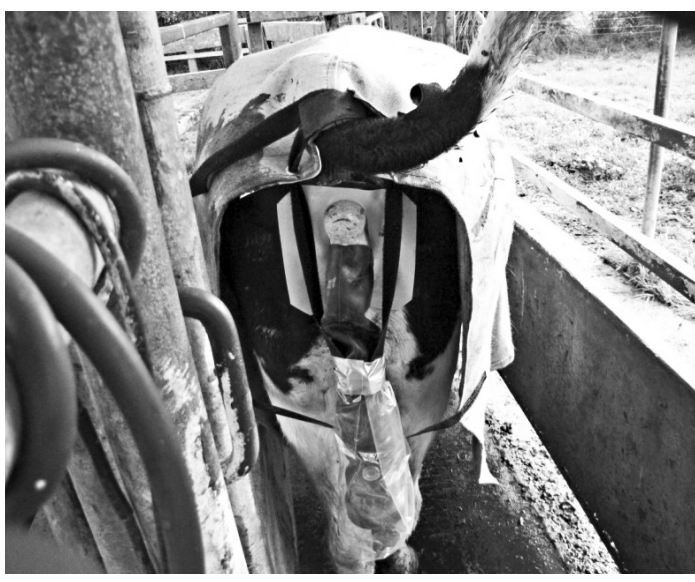

Figure 1 AgResearch urine sensor (Mark II) on a dairy cow. Two long Velcro ${ }^{\odot}$ straps hold the sensor onto the cow cover. The urine catcher is glued around the vulva and urine passes down a section of motorcycle inner tube to the urine sensor. A polythene sleeve covers the urine sensor to prevent faecal soiling. A PVC sheet, glued to the skin, prevents the straps levering the catcher from the skins, thereby allowing urine leakage.

Model" was then applied to the GPS velocity data on a cattle-grazed paddock on the Motere farm of Landcorp Limited, Taupo (Betteridge et al. 2008), to determine if the same CSAs they defined based on urine patch distribution were selected as potential hotspots by the Lying Threshold Model.

\section{AgResearch Urine Sensor MkII}

A urine "collector" is glued over the vulva of the cow to channel all urine down to the "urine sensor" suspended below it (Figure 1). The sensor is supported by two Velcro $^{\circ}$ straps attached to a cow cover. The sensor measures volume and $[\mathrm{N}]$ as urine flows to the ground. Data are downloaded by a ZigBee wireless network system to a near-by computer. At the start and end of a field campaign, the sensor is calibrated for $[\mathrm{N}]$ and volume. Although not used in this study, by triangulation, the urine sensor can determine the location of urine patches (approximate accuracy $\pm 4 \mathrm{~m}$ )

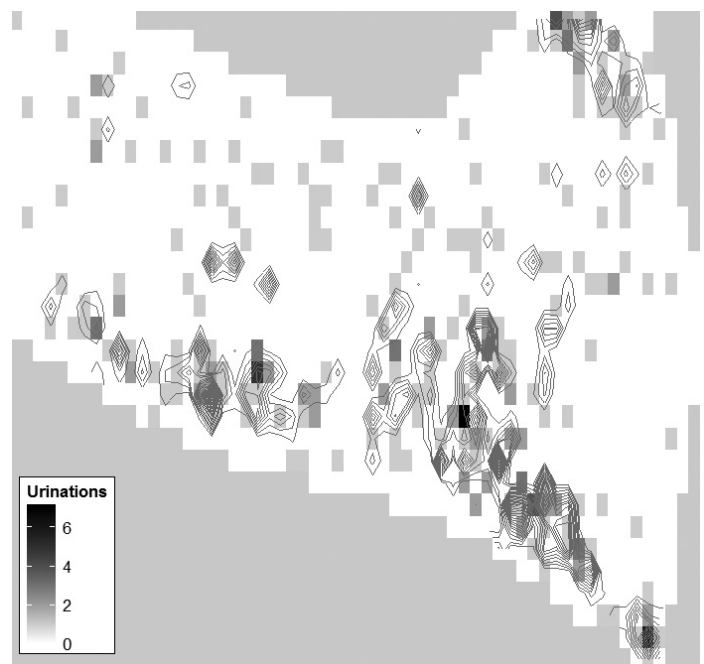

Figure 2 Contour lines created by the Lying Threshold Model showing where cows might camp in a small section of hill pasture in the Motere paddock. Grey scale grid cells show the number of urination events known to have been excreted within the 5 $\mathrm{m} \times 5 \mathrm{~m}$ grid cells.

within the paddock, using the ZigBee communication system and at least three Zigbee fixed-location "reference nodes" around the paddock perimeter.

\section{Grazing study}

Nine dry, cross-bred dairy cows were fitted with a urine sensor to quantify urine $[\mathrm{N}]$ and volume of each urination event over 11 days in August 2012. Cows were grazed in just one paddock and received a break of fresh pasture each morning to meet their maintenance requirements. A GPS, mounted on a collar, identified when cows were shifted to new pasture. The distribution of urinary $\mathrm{N}$ loads $([\mathrm{N}] \times$ volume) was described using the density curve (fitted based on the frequency of the urine deposition of different $\mathrm{N}$ loads), and was used in the estimation of $\mathrm{N}$ leaching.

\section{Modelled nitrogen loss}

Li et al. (2012) developed a framework to assess the

Table 1 Effect of using variable compared to average urine data in paddock-scale estimation of $\mathrm{N}$ leaching, for a Taupo cowgrazing system on two pumice soils. Values in parentheses are relative leaching loss (\%) compared to the estimated loss using arithmetic means.

\begin{tabular}{lcc}
\hline & \multicolumn{2}{c}{ Leached (kg N/ha/yr) } \\
Urine input source & Oruanui & Waipahihi \\
\hline Variable V and N & $43.1(90.4)$ & $62.7(90.0)$ \\
Variable N only & $45.5(95.4)$ & $66.1(94.8)$ \\
Variable V only & $48.5(101.7)$ & $70.9(101.7)$ \\
Lognormal mean V mean N & $50.4(105.7)$ & $73.5(105.5)$ \\
Arithmetic mean V and mean N & $47.7(100)$ & $69.7(100)$ \\
\hline
\end{tabular}

\footnotetext{
$\mathrm{V}$ - volume; $\mathrm{N}$ - urinary nitrogen concentration
} 


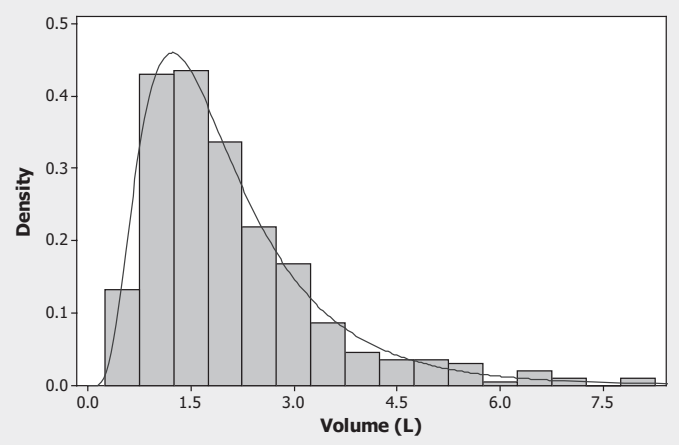

Figure 3 Densityfunction (curve) of lognormal frequency distribution of urine volume of 412 urination events by 9 dry dairy cattle over 11 days, break-grazed on fresh pasture. Cows were shifted between 9 and 11:30 am each day. Data are represented by a lognormal curve.

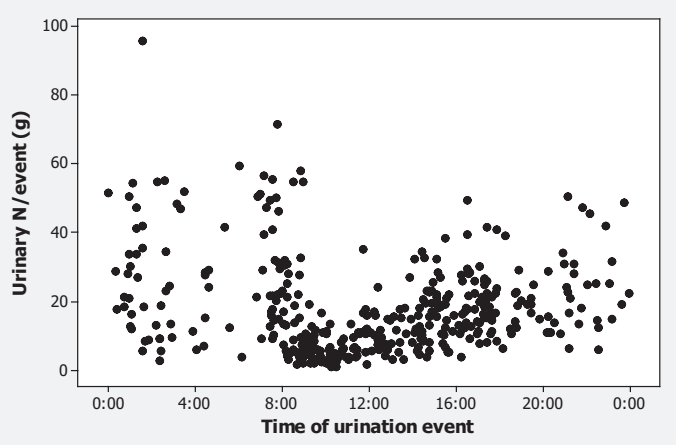

Figure 5 Diurnal pattern of total urinary nitrogen in each of 412 urination events by 9 dry dairy cattle over 11 days.

effects of varying cattle urine $[\mathrm{N}]$ and volume on the $\mathrm{N}$-leaching loss from pastures. In the framework, annual total number of urine depositions on a pasture paddock was estimated based on animal grazing days supported by a given pasture production estimate (animal·days/ $\mathrm{ha} / \mathrm{yr}$ ) and the average urine deposition events/animal/ day. The variation patterns of urine volume and urinary $\mathrm{N}$ concentration were analysed and an approach to estimate the urine patch area and, consequently, the $\mathrm{N}$ deposition rate ( $\mathrm{N}$ load), was established. The $\mathrm{N}$ leaching from variable heterogeneous urine patches was estimated using the response curves of $\mathrm{N}$ leaching to $\mathrm{N}$ load of various urine patches. The response curves were established based on the Animal Production Systems Simulator (APSIM version 7.5 (www.apsim. info)) estimation of $\mathrm{N}$ leaching from urine patches which were validated against measurements. The $\mathrm{N}$ leaching from various heterogeneous urine patches were scaled up to paddock level based on the frequency distribution of various urine patches (Li et al. 2012). We used the framework with the new observed urine

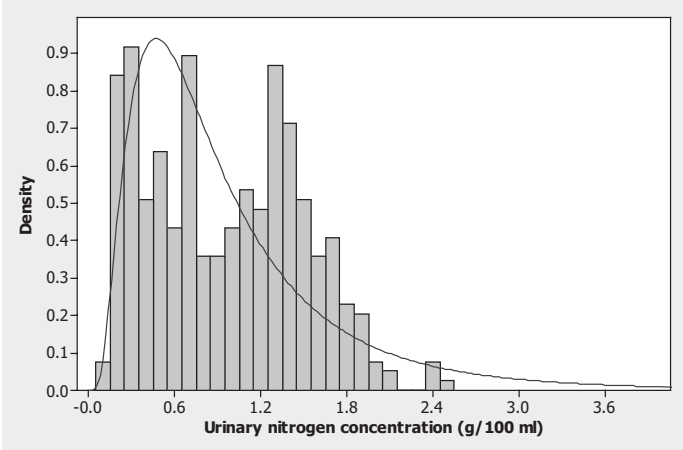

Figure 4. Densityfunction (curve) of lognormal frequency distribution of urinary [N] of 412 urination events by 9 dry dairy cattle over 11 days, break-grazed on fresh pasture. Data are represented by a lognormal curve.

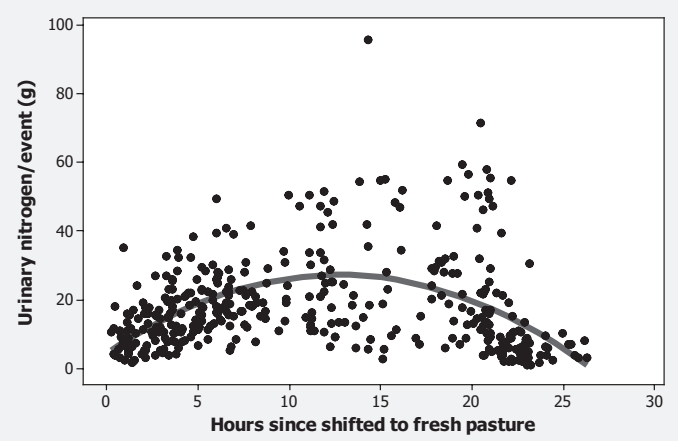

Figure 6 Urinary nitrogen/event by 9 cows over 11 days relative to when cows were shifted to new pasture (hour 0). Data are represented by a quadratic curve.

$[\mathrm{N}]$ and volume data to estimate the $\mathrm{N}$ leaching from pastures to demonstrate the effects of measuring urine volume and $[\mathrm{N}]$ to improve $\mathrm{N}$ leaching estimates from grazed pastures.

\section{Results and Discussion}

\section{Predicting critical source areas (CSAs)}

The GPS data from the Motere farm was utilised here. A "levelplot" of the number of urine events of all monitored animals within each $5 \mathrm{~m} \times 5 \mathrm{~m}$ grid cell was created, after which a contour map of animal "proxy" lying time, predicted by the Lying Threshold Model, was overlaid. It is clear in Figure 2 that the majority of urine patch areas match the proxy lying time contours, especially where there were high densities of urine events. In fact, of the grid cells with at least two urine events recorded, $86 \%$ also recorded lying events. When the urination events and lying times were accumulated over a $15 \mathrm{~m} \times 15 \mathrm{~m}$ grid (formed using adjoining $5 \mathrm{~m} \times$ $5 \mathrm{~m}$ cells), the correlation between urination events and lying time was 0.68 . Of these larger cells with at least 
one urination event, $75 \%$ also recorded lying envents. Therefore, we suggest that the Lying Threshold Model is a simple and efficient methodology for identifying CSAs within a paddock, based only on animal GPS velocity data.

The median slope for the $5 \mathrm{~m} \times 5 \mathrm{~m}$ grid cells with at least one urine event recorded was $13.2^{\circ}$. The average slope of the lower 50 percentile of cells that received up to $50 \%$ of all urination events in this hill country paddock was $8.0^{\circ}$. This supports our contention that cattle camp on low slope areas in steep hill country. In paddocks with a higher proportion of low-slope land, a greater percentage of urine would be excreted in this slope class, but all of these areas can be targeted with a mitigation product since the additional low-slope land would be safe for vehicle access.

\section{Distribution of urine volume and [N] in grazing study}

Due to the equipment developmental nature of this work, some sensors needed to be re-fitted each day. Therefore, many data were of urination events for an individual cow during only part of a $24-\mathrm{h}$ period. This might have introduced some bias in the conclusions drawn, since events overnight were typically of greater $\mathrm{N}$ loads (Figure 5) and were more likely to have been missed, since sensor failure rate increased with the passage of time. However, 412 data records were collected, being approximately $35 \%$ of potential. These gave insight into the variability in urine volume and urinary $[\mathrm{N}]$. Average volume was $2.1 \mathrm{~L}$ (SD 1.32) but volumes ranged from $0.30 \mathrm{~L}$ to $7.83 \mathrm{~L} /$ event (Figure 3). Similarly, average urinary [N] was $0.95 \mathrm{~g} \mathrm{~N} / 100 \mathrm{ml}$ $\mathrm{N}$ (SD 0.53), and ranged from 0.12 to $2.47 \mathrm{~g} \mathrm{~N} / 100 \mathrm{ml}$ (Figure 4).

\section{Diurnal pattern of urine $\mathbf{N}$ load}

The load of $\mathrm{N}$ in each urine patch averaged $18.1 \mathrm{~g}$ $\mathrm{N}$ (SD 13.8) and ranged from 1.0 to $96.0 \mathrm{~g} \mathrm{~N} / \mathrm{event}$. These data show a clear diurnal pattern (Figure 5) that is closely related to sunrise $(0710 \mathrm{~h})$ and sunset (1735 h). All cows urinated at some time during the night, and urinary $\mathrm{N}$ loads were typically higher than during daytime. At about sunrise all cows would stand and urinate relatively large $\mathrm{N}$ loads, but thereafter, loads were smaller and urination frequency was higher. After entering a new break (Figure 6, time zero), urinary $\mathrm{N}$ loads increased over the next $10 \mathrm{~h}$, reflecting the increasing amount of $\mathrm{N}$ excreted from freshly eaten pasture. This suggests that night-time urine, typically in CSAs, would result in higher rates of $\mathrm{N}$ leaching than day-time events. Thus, CSAs in hill country not only receive up to $50 \%$ of all urination events in the paddock, but also receive the most heavily N-loaded urination events. Furthermore, these urine patches in
CSAs have a higher probability of overlapping (Shorten \& Pleasants 2007) and resulting $N$ loads in soil will have an exceptionally high $\mathrm{N}$ leaching potential.

\section{Paddock-scale nitrogen leaching}

Urine characteristics from the winter break-grazing experiment were used to create the lognormal density curves for urine volume and [N] (Figures 1 and 2). The arithmetic and lognormal mean volumes were identical (2080 ml/event), but the mean of fitted lognormal distribution of $[\mathrm{N}](0.99 \mathrm{~g} \mathrm{~N} / 100 \mathrm{ml})$ was slightly higher than the arithmetic mean $(0.95 \mathrm{~g} \mathrm{~N} / 100 \mathrm{ml})$ due to the bias towards dilute urine in the curve fit (Fig 2).

Estimates of paddock-scale $\mathrm{N}$ leaching were calculated using the same pasture and cattle grazing regime on two pumice soils as described in Li et al. (2012) (viz. annual pasture production $12.5 \mathrm{t} \mathrm{DM} /$ ha of which $80 \%$ was grazed; 12 urination events/animal/day and $175 \mathrm{~kg}$ urinary $\mathrm{N}$ excreted/ha/yr) and average, versus variable urine volume and $[\mathrm{N}]$ data collected with the new urine sensor, as shown in Table 1.

The modelled $\mathrm{N}$ leaching losses using the lognormal mean urine volume and $[\mathrm{N}]$ on Oruanui and Waipahihi soils were higher than previously estimated by $\mathrm{Li}$ et al. (2012) (43.1 and $62.7 \mathrm{~kg} \mathrm{~N} /$ ha respectively) replicating the same management system, but which used a mean urine volume of $2.5 \mathrm{~L}$ and urinary $[\mathrm{N}]$ of $0.75 \mathrm{~g} \mathrm{~N} / 100$ $\mathrm{ml}$. Our mean volume was $2.1 \mathrm{~L}$ and $[\mathrm{N}]$ was $0.95 \mathrm{~g}$ $\mathrm{N} / 100 \mathrm{ml}$. Whereas the Waipahihi soil leached about $11 \%$ more $\mathrm{N} / \mathrm{ha} / \mathrm{yr}$ than the Oruanui soil, the estimated leaching loss was about $10 \%$ less where both $[\mathrm{N}]$ and volume/urination event were varied, compared to the estimate where arithmetic mean values were used as input. This considerable difference, if confirmed by further research and more "complete 24-h measurement periods", could impact a farmer's nitrogen discharge allowance where, in the Lake Taupo catchment, farming intensification is constrained by the the amount of $\mathrm{N}$ leached. The estimates presented by Li et al. (2012) used urine data from steers in warm summer weather, whereas the present data were from cows on break-fed pasture in cool winter conditions. Also, the new data set showed a different frequency distribution pattern of urinary $[\mathrm{N}]$ (Figure 4) from that estimated based on early available data. This distribution pattern has large effects on estimates of $\mathrm{N}$ leaching loss and needs to be described on the basis of more data to increase the confidence in estimating $\mathrm{N}$ leaching, especially covering the differences amongst seasons and between animal gender. Consideration around pasture composition and $\mathrm{N}$ content of pasture over seasons is required.

Because $\mathrm{N}$ leaching increases exponentially as the load of $\mathrm{N}$ in a urine patch increases (Ledgard 2001), paddock-scale leaching losses will be dominated by 
the influence of patches with the highest $\mathrm{N}$ Load. The greatest risk of $\mathrm{N}$ polluting waterways is where CSAs are close to waterways or overland-flow channels. However, with CSAs in cattle-grazed hill country being found generally on small flat areas, up to $50 \%$ of all urination events can potentially be targeted with an appropriate $\mathrm{N}$-loss mitigation tool.

Because urine $[\mathrm{N}]$ and volume from our group of cows was highly variable, with coefficients of variation being $\geq 60 \%$, $\mathrm{N}$ leaching estimates scaled to the whole paddock, but based on lysimeter experiments using single or bulked (mean) urine samples, may be incorrect.

To obtain a better understanding of the impact of variable urine volume and $\mathrm{N}$ concentration on paddock scale leaching, a more extensive study, providing complete 24-h data sets, is required.

The simulated targeting of dicyandiamide (DCD) only at CSAs in a steep hill environment where campsites occupied by just $10 \%$ of the paddock area, was shown to be cost effective in a simple economic analysis when targeting autumn-winter applied DCD (Betteridge et al. 2011). However, in both lowland and hill country, the most easily identified CSAs are likely to be the stripgrazed pastures and forage crops areas of the farm which are invariably located on flat paddocks that can be readily treated with chemicals.

As DCD on grazed pastures is now suspended, alternative strategies are required. One of these is the use of salt used as a diuretic (Ledgard et al. 2006). Our urine sensor is well suited to quantify the effect of salt, or other diuretics, on urine volume and urinary $[\mathrm{N}]$.

Since, in this break-feeding situation, the estimated $\mathrm{N}$ load/urination event was higher at night-time than during than day-time, such loads will generally be deposited in stock camps. Thus, from the point of view of targeting mitigation strategies, knowledge of where stock camps are located in a paddock is important.

The correspondence of the Lying Threshold Model (GPS velocity) predicted campsite locations with the known sites of urine aggregation from an earlier study at Motere, confirms that cow CSAs in hill country pastures can be determined from GPS data. However, as the campsites created by those cows were on land with a mean slope of $8^{\circ}$, farmers would need only a paddock topographic map with which to determine where mitigation strategies should be targeted, such that up to $50 \%$ of all urination events could be treated to reduce $\mathrm{N}$ leaching and nitrous oxide emissions (Betteridge et al. 2011).

\section{ACKNOWLEDGEMENTS}

AgResearch Ballantrae farm staff John Napier and Brad Gordon, Landcorp Ltd and Motere farm staff; French
Interns Guillaume Vigneron, Raphaelle Houin, Sophie Balladur and Samuel Martin; and Massey University farm staff are thanked for assistance with running the trials and preparing the data for analyses. This project was funded by the Sustainable Farming Fund SFF 10-088, FertResearch, Lake Taupo Protection Trust, TracMap Ltd and the Ministry of Business, Innovation and Employment C10X1006.

\section{REFERENCES}

Betteridge, K.; Andrewes, W.G.K.; Sedcole, J.R. 1986. Intake and excretion of nitrogen, potassium and phosphorus by grazing steers. Journal of Agricultural Science 106: 393-404.

Betteridge, K.; Costall, D.; Balladur, S.; Upsdell, M.; Umemura, K. 2010a. Urine distribution and grazing behaviour of female sheep and cattle grazing a steep New Zealand hill pasture. Animal Production Science 50: 624-629.

Betteridge, K.; Costall, D.; Lou, D.; Ganesh, S.; Sun, H. 2013. Development of a critical source area prediction model of nitrogen leaching. In: Accurate and efficient use of nutrients on farms. Eds. Currie, L.D. ; Christensen, C L. http://www.massey. ac.nz/ flrc/publications.html Occasional Report No. 26. Fertilizer and Lime Research Centre, Massey University, Palmerston North, New Zealand. 8 pp.

Betteridge, K.; Ganesh, S.; Luo, D.; Kawamura, K.; Costall, D.; Yoshitoshi, R. 2012. A methodology for determining critical source areas of nitrogen in grazed hill pastures. In: Advanced Nutrient Management: Gains from the Past - Goals for the Future. Eds. Currie, L.D. ; Christensen, C L. http://www.massey. ac.nz/ flrc/publications.html Occasional Report No. 25. Fertilizer and Lime Research Centre, Massey University, Palmerston North, New Zealand. 10 pages.

Betteridge, K.; Hoogendoorn, C.; Costall, D.; Carter, M.; Griffiths, W. 2010b. Sensors for detecting and logging spatial distribution of urine from grazing cows and ewes. Computers and Electronics in Agriculture 73: 66-73.

Betteridge, K.; Kawamura, K.; Costall, D.; Carter, M.; Hoogendoorn, C.; Griffiths, W.; Inoue, Y. 2008. Tools to determine impact of animal behaviour on nitrogen leaching and nitrous oxide emissions. pp 286-298 In: Carbon and Nutrient Management in Agriculture. Eds. Currie, L.D.; Yates, L. J. Proceedings of the Fertiliser and Lime Research Centre Conference, Occasional Report No. 21.

Betteridge, K.; Li, F.; Costall, D.; Roberts, A.; Catto, W.; Richardson, A.; Gates, J. 2011. Targeting DCD at critical source areas as a nitrogen mitigation strategy for hill country farmers. In: Adding to the 
knowledge base for the nutrient manager. Eds. Currie, L.D. ; Christensen, C L. http://www.massey. ac.nz/ flrc/publications.html Occasional Report No. 24. Fertilizer and Lime Research Centre, Massey University, Palmerston North, New Zealand. 13 pages Ledgard, S.F. 2001. Nitrogen cycling in low input legume-based agriculture, with emphasis on legume/ grass pastures Plant and Soil 228: 43-59.

Ledgard, S.F.; Menneer, J.; Welten, B.; Kear, M.; Dexter, M.; Lindsey, S.; Betteridge, K.; Crush, J.R.; Pacheco, D. 2006. New nitrogen mitigation technologies for evaluation in the Lake Taupo catchment. pp. 19-24. In: Designing Sustainable Farm Systems: Critical Aspects of Soil and Water Management.
Eds. Currie, L.D.; Hanly, J.A.. Occasional Report No. 19. Fertilizer and Lime Research Centre, Massey University, Palmerston North, New Zealand.

Li, F.Y., Betteridge, K; Cichota, R.; Hoogendoorn, C. J.; Jolly, B.H. 2012. Effects of nitrogen load variation in animal urination events on nitrogen leaching from grazing systems. Agricultural Ecosystems and Environment 159: 81-89.

Shorten, P.R.; Pleasants, A.B. 2007. A stochastic model of urinary nitrogen and water flow in grassland soil in New Zealand. Agriculture, Ecosystems \& Environment 120: 145-152. 